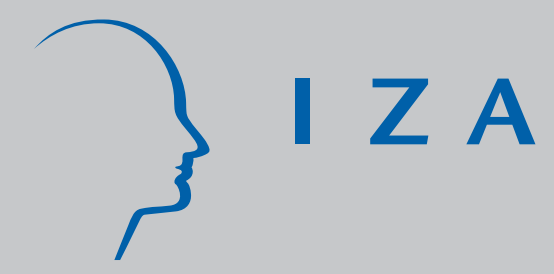

IZA DP No. 3247

Labor Market Policy Options of the Kurdistan Regional Government

Almas Heshmati

December 2007 


\title{
Labor Market Policy Options of the Kurdistan Regional Government
}

\author{
Almas Heshmati \\ University of Kurdistan Hawler, \\ HIEPR and IZA \\ Discussion Paper No. 3247 \\ December 2007 \\ IZA \\ P.O. Box 7240 \\ 53072 Bonn \\ Germany \\ Phone: +49-228-3894-0 \\ Fax: +49-228-3894-180 \\ E-mail: iza@iza.org
}

\begin{abstract}
Any opinions expressed here are those of the author(s) and not those of the institute. Research disseminated by IZA may include views on policy, but the institute itself takes no institutional policy positions.

The Institute for the Study of Labor (IZA) in Bonn is a local and virtual international research center and a place of communication between science, politics and business. IZA is an independent nonprofit company supported by Deutsche Post World Net. The center is associated with the University of Bonn and offers a stimulating research environment through its research networks, research support, and visitors and doctoral programs. IZA engages in (i) original and internationally competitive research in all fields of labor economics, (ii) development of policy concepts, and (iii) dissemination of research results and concepts to the interested public.
\end{abstract}

IZA Discussion Papers often represent preliminary work and are circulated to encourage discussion. Citation of such a paper should account for its provisional character. A revised version may be available directly from the author. 
IZA Discussion Paper No. 3247

December 2007

\section{ABSTRACT}

\section{Labor Market Policy Options of the Kurdistan Regional Government ${ }^{\star}$}

This study is a descriptive analysis of the labor market conditions in Iraqi Federal Kurdistan Region. It explores a number of integrated factors that covariate and determine the level and patterns of the labor market outcomes in the region. In the first step, each of the determinants of unemployment is described and establishes their causal and directions of possible effects. In the second step, the characteristic of the current labor market policy is investigated. Finally, after providing knowledge about the nature of (un)employment and current policy measures, a number policy measures are proposed to reduce the rate of unemployment or to reduce the negative effects of unemployment and to promote skills, capability and development potential.

JEL Classification: E24, I28, J24, J31, J45

Keywords: employment, mismatch, government policy, skills, wages, public sector, Kurdistan

Corresponding author:

Almas Heshmati

University of Kurdistan Hawler

30 metri Zaniary

Hawler

The Federal Region of Kurdistan

Iraq

E-mail: Heshmati@snu.ac.kr

\footnotetext{
* I would like to thank Dr. Motasam Tatahi and Mr. Taher Khaledi for their comments on an earlier version of this paper.
} 


\section{Introduction}

Currently there are no labor market statistics available that cover the Federal Region of Kurdistan. Lack of basic labor market statistics does not allow researchers to quantify the extent of unemployment in the region and to analyze its negative distribution and social and welfare effects. Unlike the rest of Iraq, in recent years the conditions have been optimal such that the labor market could operate differently than those of the rest of country. The main reason for the gap between the actual and potential outcome is lack of a qualified statisticians to collect and process data on a systematic basis. Despite significant resources allocated to collection and process of data since 2002, still no data, regardless of economic or social area, is available that can be used for research and policy analysis. This is an indication of the failure of the current system of data collection and implying that necessary steps are needed to be taken to redirect the efforts and better utilization of scarce resources. It is urgent to introduce changes in the organization and responsibility of data collecting agencies such that necessary data is produced and delivered to researchers and policy makers.

The section of any regional Bureau of Statistics specialized on collection of labor market statistics should collect information on a number of issues such as: analysis and prognosis about education and labor market; workplace environment, safety, accident and work absent; wages and labor costs; employment and labor market participation; work hours; vacancy and unemployment rates, and several other location and region specific factors. Many of the above areas should be designed such that it covers: job turnover or job creation and job destructions; distribution of labor by a number of key characteristics such as by gender, age and education; distribution of labor by economic sector into public and private, agriculture and manufacturing, urban and rural areas; distribution of labor by location such as cities and sub-regions, resident and non-resident, foreign and domestic workforce; distribution of unemployment by each of the characteristics above. These types and magnitudes of statistics collected covering all regions and in stratified form will enrich decision making and forecasts that results in optimal decision making and effective resource utilization.

In this essay, I present a brief and descriptive analysis of the labor market conditions in Federal Region of Kurdistan in general and those in the city of Hawler in particular. I explore a number factors that very likely covariate and are considered as determinants of both the level and patterns of the labor market outcomes in the region. The list can be quite long but here focus of a few most important factors including: mismatch of 
education and skills required on the job market; low quality of education and insufficient to create new job opportunities; high wage rate resulting in low relative labor productivity and competitiveness in the region; lowering capital investment, high risk and unknown prospects for future development; high profitability of import and distribution compared to local production; and finally the absence of well-functioning labor market institutions, lack of statistics and active labor market policy measures to promote production and employment creation. In the first step, I describe each of the determinants of unemployment and establish their possible causal relationships, its direction and possible effects. In the absence of local experience, reference is made to experience from neighboring countries and case studies elsewhere. In the second step, investigate the characteristics of the current labor market policy. Finally, a number of policy measures are proposed to reduce the rate of unemployment or to reduce the negative effects of unemployment and to promote skills, capability and development potential.

\section{Mismatch of education and skills demanded}

Job market in a modern economy is seen as a transformation process characterized by destruction of old and creation of new jobs. In recent decades we have witnessed, that the technology changes much faster than ever before. In a globalized world and with access to modern information and communication technology, old technologies are scrapped and new technologies are introduced with much shorter commercialization time and life expectancy. As a result, jobs in sectors with old technology producing goods not demanded, having low quality and non-competitive are destructed or outsourced to countries with low labor cost such as India, Vietnam and China. Vietnam is one of the many countries that in recent decades made serious efforts to reform its economy and be part of the new wave of globalization process. The economic reform (1986) in Vietnam included measures to liberalize the labor market but salary reform was introduced later (1993) with low rate of return to education (Moock, Patrinos and Venkataraman, 2003). The low level of return to education was also observed in the case of China, although it has increased as the transition process has deepened ( $\mathrm{Li}$, 2003). In both countries significant progress has been made to reduce the mismatched gap.

In parallel with the job destruction process, new technology and jobs are created in 
association with new products and processes. Many of new jobs are not demand driven rather are innovation based, where new or modified products and processes are introduced in the market in their search for generation of demands. Most of the investments in socio-economic policy measures in general and those in the job market policy measures in particular, are aimed at balancing between old jobs destructed and new jobs created. A positive net job turnover and by accounting for population flows and growth is the aims of such policies. Depending on conditions, the process has strong implications for the labor market outcomes and it effects differ across different labor categories. For instance, Belzil (2000) using Danish firm level data estimated the effects of job creation/destruction and worker reallocation on wages. Job creation is found to increase male wages. In general entry wages and wages of low tenure workers and females appear much more sensitive to job turnovers than wages of workers who are already employed.

There are several studies that discuss outcome of labor market policies in the Middle-East. The effect of export-oriented growth strategy on female labor force participation and employment in Turkey is analyzed by Baslevent and Onaran (2004). The long term economic growth at the province level have a significant impact on labor market outcomes for females, but the effects of export orientation is not as strong and more pronounced in the case of unmarried woman. Miles (2002) finds that gender system influences employment and unemployment patterns in Jordan. Cultural and family level factors determine women's participation in the labor market as well as their success in finding a job. State and employer level factors and shrinking public sector also affects disproportionately females' unemployment rate. Assaad and Arntz (2005) find increasing gender gap (in access to wages and employment) in Egypt which is attributed to women's more limited geographical mobility. Government employment in the Middle-East and North Africa (MENA) region as a means of keeping people employed and out of poverty has reduced the level and dept or severity of poverty in the region (Adams and Page, 2003).

The rise of the New Economy or the knowledge based economy has generated new global infrastructure with information and communication technology playing an increasingly important role in the national as well as global economies. In most countries the education system has expanded and new institutions have been established to serve populations that previously had little access to higher education. Reduced funds and increased number of students implies that higher education must improve their 
administrative efficiency and accountability in response to demand from government, business, industry and the candidates. Mok (2005) analyzed strategies adopted by the universities in Hong Kong to promote entrepreneurial spirit and practices of their academic staff to make students more creative, innovative and international. Government plays a key role to the interaction between the government and the private sector and the education sector to promote a dynamic economy.

Modernization of the education system ${ }^{1}$ and its competitiveness and compliance with a modern economy and world is a thus a prerequisite for a balanced and sustainable economic development. Corporations cannot survive by producing only for a local market as economies are open and both economy and firms are increasingly subject to international competition. The standards are set by technologically and cost effective progressive and advantages countries. No society can last in the long run without ability to adopt, to create, to compete and to exchange. The Middle-East model of development based on massive export of oil, import and distribution of all commodities and excessive consumption with simultaneous and systematic destruction of their own technology and sources of life as an outcome is a non-sustainable approach of business and an obvious failure of governance and institutions in those countries. Thus, the linkage between innovation, technology, education, learning, capability, job market, production, competition, exchange and consumption are important to the development policies and their impacts in an economy and society.

The issue of matching education and skills required for the economy to function effectively is very important element of an educational policy and system. The educational system is expected to prepare the workforce in a society for internal creation and external competition and to have the ability to exchange products and services under the framework of free competition and balanced trade relationships. The aim is to minimize the magnitude of mismatch. An extended mismatch will result in low competitiveness of the economy and increased unemployment and loss of welfare. Thus, policy makers and planners have a crucial role in the allocation of scarce resources. It is

\footnotetext{
${ }^{1}$ The issue of reform and modernization of the education system in the Federal Region of Kurdistan will be discussed in a separate report. Currently, I am preparing the report by reviewing the reform process and evaluation of the outcomes from several case studies mainly but not limited to the transition economies with comprehensive and rapid reform of their education sector. The review include the following country studies: Vietnam (Moock, Patrinos and Venkataraman, 2003), China (Li, 2003) Latin America (Castro and Levy, 2000), Estonia (Tomusk, 2001), Lithuania (Thomas, 2001), Portugal (Amaral and Tixeeira, 2000), Turkey (Dundar and Lewis, 1999), Mongolia (Walters et al. 1999), Botswana (Marope, 1996), European countries (Bleiklie, 2000) and Japan (Reiko, 2001).
} 
important that the planers systematically study the development at the global level and evaluate the local potential and ability to act in a global perspective. This will guide them in quantification of human capital needed and its distribution, but also identification of the weaknesses and strength to be reflected in allocation of resources and investment policies. Forecasts of quantity of needed skills, allocation of resources and distribution of specializations is an important step to be taken.

\section{Low quality of education and inability to create new job opportunities}

The high dependency of the Kurdish society on foreign skilled labor during the recent years of boom in building up the infrastructure and reconstruction activities is a direct result of the low quality of education in Kurdistan. In my understanding the low quality is a result of long period of lacking resources, organizational changes, rapid expansion of the capacity and probably even mismanagement of the higher education. Since 2003 significant resources have been allocated to universities. It is desired that the outcome of such investment is evaluated to quantify the effects and its distribution across different universities and institutes of the higher as well as lower education.

The living conditions, insecurity and internationally non-competitive wages and salaries, non-transparency of the system, probably abuse of power and influence and general employment conditions might have affected the brain drain process and in parallel have prevented repatriation of educated Kurds living abroad. The resulting education system produces graduates that are not well trained or creative and not sufficient modern in technology upgrading to form a society with high degree of self-sufficiency in skilled and educated work force. These negative qualities of the workforce together with low incentives and work moral are factors responsible for the fact that not enough jobs are created to absorb the young and graduate labor force.

The negative development is shown in the recent increasing trend in the emigration of the young population from the region to Europe where their skills are not fully utilized. Instead of learning new skills and repatriate in future, very likely under the best conditions they end up in low skilled jobs, where they loss their earned university skills. In the worst case the emigrants will depend on the host countries social security system and become a burden for those societies and to no help to the Federal Region of Kurdistan. Thus, quality of education and necessary training to acquire skills useful in practice are crucial determinants of job creation and welfare of the citizens. In a related 
study Mehta (2000) treats higher quality of education as a form of technical progress resulting in productivity changes that yield different gainers and losers. Declines in the quality of education generally lead to an increase in different forms of inequality such as opportunities, but foremost income inequality.

\section{High wage rate, low relative labor productivity and competitiveness}

The levels of wages should be determined by productivity of labor and such that it covers the normal living expenses for a normal sized family. Currently, the wage level is quite high and without doubt in non-parity with level of productivity or level of education of labor. There are several factors causing the rapid development of the prices in general. The wages have increased dramatically as a result of dollarization of the economy affecting the prices of services produced locally and goods imported. There is evidence that an in-optimal wage setting affects the employment and production factor decisions (Heshmati and Haouas, 2004). In recent months many of the main employers in the region are hiring foreign low skilled workers in services where local labor force are not willing to take since they receive salaries from the public service for doing nothing. The generous public employment policy has resulted in misallocation of scarce public resources, low pay off for education, massive laziness, high expectation, low work moral and non-participation of many Kurds in the development of their economy.

Another factor causing increased wage level is the informal employment procedure, which might not be open and determined in competition or by following some salary scale guidelines, rather it might be determined on an individual basis and affected by the way that employees are hired through recommendations from higher ranks. If this true, it will created a job market that is an outcome of exchange of service among people in decision making position and a matter of hiring relatives and friend who do not disclose unacceptable work practices at the public institutions. It will in turn create a corrupt system and harmful to accountability of public institutions. Since available job openings are available almost only in the public sector, wage setting might be a reflection of favoring relative and friends rather then the level of skills or education of the employees. In such system, education is not a factor of qualification for job applications, rather than a degree to legitimize occupation of a job that the employer has no specific skills for.

The labor productivity ${ }^{2}$ is very low for the reasons of low skilled labor, corrupt

\footnotetext{
${ }^{2}$ For review of alternative measures of productivity growth, efficiency and outsourcing in manufacturing
} 
employment system, low work moral and misplacement of the work force. A low labor productivity combined with high employment rates and wages is one main source of high inflation rate that has affected negatively the economic development and living conditions for the poor sector of the society. The low labor productivity and a high wage rate are two main effective factors not only preventing inflow of foreign direct investment to the region but also causing outflow of domestic capital to finance development projects elsewhere ${ }^{3}$. They also make investment by domestic investors impossible as they might have better alternative investment opportunities elsewhere. The labor cost as a competitive factor in production in Kurdistan does not exist. The high labor cost and inflation rate steer away investors from the region.

\section{Low capital investment, high risk and unknown future development}

The low level of infrastructure and investment capacity results in a low rate of actual capital investment then it could have been under normal conditions. The capital investment rate is low because of outflow of capital from the region due to lacking attractive investment opportunities to encourage capital investment in the region. Since investment programs with the magnitude observed in recent years in the Kurdistan region is a new phenomenon, there is little experience in identification of investment opportunities and on factor determining a decision of investment. There is lacking necessary experience and efforts to improve upon the smooth function of the hardly existing or incomplete financial market through regulations.

The geographic condition, excess of money supply together with the recent 3 years of comprehensive public investment programs in infrastructure has led to high returns on investment in the region. Despite good opportunities to make a profitable investment in Kurdistan, there are high risks associated with investment in Kurdistan which reduces the optimal level of investment. The risks are mainly related to high and increasing inflation rate and subsequent loss of basic investment capital. Another risk factor is the regional government's direct and the influential person's indirect interventions in business relations. The increasing incomes, population and growing urbanization have led to high consumption rate which in turn has minimized the risks associated with

\footnotetext{
and service industries see Heshmati (2003).

${ }^{3}$ For analysis of global determinants of inflow of foreign direct investment to developing countries with particular emphasis on the impacts of information and communication technology infrastructure and democratization see Addison and Heshmati (2004).
} 
business in the region including storage of large quantities of imported commodities.

For several reasons the future business climate is to a large extent unknown to both public decision makers and the potential private investors. There is also lack of clear regulations for the financial market in general and capital investments in particular. Under such circumstances the actors of the market behave very much on a short run perspective. Actors investing under certainty and on a long term bases are excluded from the market. Short run investment behavior has several disadvantages for the region among other: high return expectations and low investment in infrastructure, organization, management and training. Transfer of return earnings to abroad is an indication of discontinuity in investment plans. The overall cost to the society will be high in form of lost opportunities, high prices and lost tax revenues, no permanent job opportunities and little spillover effects and technology and skill transfers from multinational corporations and foreign investors.

\section{High profitability of imports and distribution compared to local production}

In the Middle-East, it is quite common that individual countries in the region import the same commodities for a long time period, without any efforts made to understand the nature of the product, to learn the skills to modify it for local needs, to produce it or through different kinds of support and trade contracts to facilitate transfer the production and technology to the region. This behavior of lacking incentives to learn is probably the main factor causing the reverse development in the region and their backwardness in self-sufficiency, technology capability and development.

Almost all domestic capital is used to import and distribute commodities. This behavior has resulted in systematic elimination of local production and development potential. Societies are created where hardly any regulations or incentives are found that promotes local solutions. Public investments are not to enhance development rather than to facilitate and to support influential people's businesses or business linkages. The welfare of public is always traded for private interests.

Under the existing conditions, it is hard to believe that quality of locally produced goods will be such that they compete with imported goods. Despite the large gap, I would find it optimal to accept inferior goods but efforts to be made to create conditions for trade and exchange with other countries technologically preferred as trade partners. Every society depending on their unique conditions has advantages in a number of areas that 
could be used in their trade relations. Local production might be inferior to imported goods, but the former has values that are not found in imported goods. Regulations of trade and the use of gained experiences from the past 50 years of import substitution policies should be taken into accounted in the design of trade policies of the region. The Chinese successfully implemented policy of trading 'Market for Technology' should provide an excellent example of successful policy of technology and skill transfer.

\section{Labor market institutions}

There are not many labor market institutions established in Kurdistan working with a modern labor market and related issues. Below I have listed a number of such institutions the majority of which are of a national character and necessary to plan and implement active labor market policies and the following evaluations of their effectiveness. The list is far from complete for a modern state but it shows the importance and types of organizations needed to be established. These institutions are necessary for reforming any labor market and its transformation to achieve optimal and efficient labor use. Haouas, Yagoubi and Heshmati (2003) and Masso and Heshmati (2004) analyze the labor use efficiency during the process of trade liberalization in Tunisia and transition of the Estonian Economy, respectively. The institutions are divided into: primary and other labor market organizations, research and evaluation related institutes, supervisory authorities, trade and investment promotion agencies, welfare, education and job market oriented training authorities. If required, a short description of each institutions primary task will be supplied and on-line references will be given to examples of such organizations, their operations and performance.

\section{A. Labor Market Organizations:}

- Employee’s Organization

- Employer’s Organization

- Labor Market Offices

B. Other Labor Market Organizations:

- Work Environment and Safety Authority

- Council for Working Life and Social Research

- Equal Opportunity Authority

- Board for Youth Affairs 
C. Research Related Institutes:

- Labor Market Policy Evaluation

- Institute for Growth Policy Studies

- Research Institute for Economic and Policy Analysis

- Bureau of Statistics

- Public and Private Research Foundations

D. Supervisory Authorities:

- Supervisory Board for Public Accountants

- Financial Supervisory Authority

- Economic Crime Bureau

- Agency for Government Contacts

F. Trade and Investment Promotion Agencies:

- $\quad$ Board of Trade

- Institute for Quality Assurance

- Agency for Economic Development and Regional Growth

- Administrative Development Support Agency

- Regional and Development Banks

- Foreign Direct Investment Agency

- Patent and Registration Office

- Competition Authority

- Export Credit Guarantee Board

G. Welfare and Training Organizations:

- Public Education

- Food Industry Administration

- Workplace Training Programs

- Tax Authority

- Board of Health and Welfare

- Consumer Authority

\section{Economic development plan}


Currently the regional government has no comprehensive economic development plan ${ }^{4}$ with detailed description of each of the components of the economic policy, their interrelations, the objectives and policy measures to achieve its development goals. Such four to five years plans are necessary to have a clear picture of the flow of resources and their utilization in achievement of targets. The conditions, targets and priorities might change due to many internal and external factors. These changes must be taken into account in the continuous process of modification of previously established goals and in the formation of new strategies. Intensive research on the design of such comprehensive economic plans and strategies and their evaluations is needed to guide the government in its economic and social policy decision makings and implementation of its development and welfare policies. It is surprising that so far nothing is written about the political economy of the Federal Region of Kurdistan or the political economy of a Kurdish state.

For reasons most of which seem to be beyond the control of the regional government, the flows of resources are irregular making long term decisions rather difficult. There is little evidence of any systematic cost benefit analysis conducted by the government to select projects that are socially preferable and gives the largest net benefits. I would guess that currently projects are not financed in competition or based on socially preferable selection mechanism, rather than based on an arbitrarily selection procedure where decisions are influenced by trust between the public authorities and people proposing different projects to be implemented and as well as personal relations. Furthermore, the high dependency of the region on imported commodities has led to severe difficulties in making budget calculations that are realistic and close to the actual final budgeted project costs. The uncertainty and subsequent delays and excessive costs are negative factors to the development resulting in frequent and significant over-use of scarce resources.

After the end of the War in Iraq, reconstruction of massively destructed public infrastructure and heavy indebtedness of Iraq very likely will severely limit the availability of resources for development in the Federal Region of Kurdistan. Current and exceptional opportunity of peaceful governance and reconstruction in the region thus should be used in the best way to build up a strong and self-sufficient base for

\footnotetext{
${ }^{4}$ For examples of such economic development plans with reference to the policy and process of industrialization in Japan, Korea and Singapore see Okimoto (1989), Minami et al. (1995), Brabscomb and Kim (1996) and Taylor (2003).
} 
economic and social development in Kurdistan region. An ineffective use of resources will generate not only public anger, but also dissatisfaction of the central government with governance of the region and management of resources leading to escalation of conflicts between the two central and regional levels of governance. Altogether, it will endanger all achievements made in the near past years of unique local self-governance. Intensive and specialized short evenings and weekends training programs lasting two to three months should be organized for advisors in the regional government and public institutions. This kind of training programs is a good complement to regular Mater of Science programs given at research regular universities to train researchers to investigate implementation of different public development programs and to evaluate their outcomes.

Given the discussion above, it is reasonable to mention that currently there is no long-term economic plan and beside the flow of resources is highly irregular and subject to high risks and major uncertainty. The important question in this regard is, what would be appropriate to propose as labor market policy for the region? It should be noted that, such policy measures are proposed under the condition of absolutely no statistics in whatever form are available which make it rather difficult if not impossible to be accurate. The critical situation is a embarrassment for the statistician and the Bureau of Statistics in this society. I do not find words to describe the unacceptable situation and statistician obvious negligence in doing their job.

\section{Active labor market policy measures}

An active and effective labor market policy for the region should incorporate simultaneously a number of policy measures including elements or subsets of the following measures. The measures are not complete but might be sufficient in the short term to introduce major improvements in the function of the Kurdistan region's labor market. It should be noted that, an implementation of each measure prior to their recommendations requires careful investigation of their associated costs and effects and its comparison with alternative policy measures. The most urgent step to be taken is to set up a committee consisting of experts and representatives from labor market parts to investigate the labor market conditions and based on which to formulate a general labor market policy program as part of which to recommend a selection of appropriate policy measures to the regional government. Care should be made in composition, skill and 
impartiality of the committee members and not to create unnecessary bureaucratic procedures.

\section{A The young workforce and investment in higher education}

It is obvious that there is shortage of experts in every stage of decision making and levels of organization and institutions in Kurdistan. Local higher education is not able to train experts in different fields needed and capable of working professionally with advanced investigations and evaluations. There is a need to reform the higher education to produce skills that are corresponding to the human capital needed and to promote a sustainable economic and social development. One could take advantage of the experience gained from the reform of education in several transition economies (see footnote 1).

Particular attention should be paid to the job market for the young university graduates. This category of job applicant is increasingly facing difficulties in entering the job market. The cause might be over-education of university graduates, lack of work experience, high expectations of the young generation, or recent years of rapid expansion resulting in lower quality of education and lack of creativity of the new graduates in job creations. There are a number of studies that are relevant to the situation for young university graduates in Kurdistan. For instance, Tasci and Tansel (2005) analyze the determinants of transition in the Turkish labor market states between employment, unemployment and out-of-the labor force by individual characteristics. University graduates are more likely to find employment compared to non-graduates and younger individuals more likely lose a job and older individuals are less likely to find a job from unemployment.

Cardoso (2004) investigates whether following the expansion of the higher education in Portugal workers with university degree increasingly fill job openings meant for workers with lower levels of schooling. Results show that the university wage premium increased in some sectors indicating no support for the skepticism over investment in higher education. In another study Cardoso and Ferreira (2002) analyzed job creation and job destruction for university graduate in Portugal. Results show that the unemployment rate can provide misleading idea of the dynamics in labor demand and employment prospects for university graduates. Again no support is found for the skepticism over investment and returns to higher education. Using British data, Walker 
and Zhu (2005) did not find evidence that the mean return to degree dropped in response to large increase in the flow of graduate. However, difference in wage fall by cohorts is observed.

\section{B Repatriation programs}

My personal experience, suggests that there are tendencies that in general local Kurds in high positions are not in favor of getting advice from non-Iraqi Kurds who have returned to the Federal Region to support the unique opportunity that Kurds have been provided to change their situation. Those who on a free choice basis have returned to serve their country and its people including myself are dissatisfied with the working conditions. We are in different ways prevented from or not given resources or opportunity needed to support the development in the way that we are able to. The main reason seems to be our complete lack of interest to get involved in business relations and simply focus on the primary tasks. It is really a waste of resources and energy to work under such conditions. It certainly has very negative effects on future repatriation efforts from the skillful first and second generation Kurds living abroad. In the migration literature, wage differentials are often cited as an important factor explaining skilled migration. Gungör and Tansel (2005) find economic instability in Turkey and high salaries offered by the host country and life style preferences of individuals to determine the non-return intentions of students and Turkish professional. The current situation with increasing migration of university graduate and lack of active policies to repatriate Kurds are very harmful to the development of the region.

\section{C Other incentive measures}

The existing student aid program might have affected enrolment rate to the higher education. The current unconditional student aid program could be improved by introducing elements of state-sponsored merit scholarships to promote and reward academic achievement to induce greater investment in human capital (see Cornwell, Lee and Mustard, 2006). Evaluation of the effectiveness of recent reform of student aid in Germany targeting students from low income families shows that the reform had only a small positive effect on enrolment rates (Baumgartner and Steiner, 2001). The higher education capacity in Kurdistan is also increased significantly in recent years. Given the shortage of skilled workforce and experts, the main source of experts in the short term is 
repatriation of Kurdish experts from industrialized countries. The Kurds of Iraq residing in industrialized countries are either reluctant to return, have no expertise knowledge or have preferences to return for doing business rather than working as experts and advisors in the public sector.

In addition to the reform of higher education, significant investment in human capital and creativity should be made to improve the individual and society's capability to create new jobs and to reduce unemployment. The process is long and it requires good planning and enormous resources to be invested in such programs. Fortunately, sufficient resources are already allocated to the higher education. It is a matter of changes in the preferences, attitudes, behaviors and reallocation of existing resources to more urgently needed types of education and training. More emphasis should be given to creativity at different levels and technology capability. Youth training and placement programs should be given a high priority to reverse the trend in outflow of youth people from the region and great loss of productive human capital. Several incentives and measures to promote a positive development such as wage subsidies, corporate tax deductions, credit guarantees and start up business programs should be introduced.

\section{D Structural adjustment measures}

In the above list among the labor market institutions required to be established as soon as possible are: labor market offices, equal opportunity authority, board for youth affairs, institutes for labor market policy evaluation, research institute for economic and policy analysis, bureau of statistics, public adult education and authorities for skill and productivity enhancing workplace training programs. Close cooperation between different institutions and the labor market parts is a prerequisite for the success of labor market and different employment programs. However, there is a risk that the established institutions result in a bureaucratic system which combined with lack of experience in implementation of labor market policy to develop into an expensive and complex project binding most of the regions resources for only little use. A gradual and stepwise implementation and in parallel continuous evaluation might be an effective strategy to save resources and to avoid project failures.

It is quite important that in a systematic way different ideas and proposals are collected by the labor market offices and institutions, and researchers conduct cost benefit evaluations of project proposals and based on which recommend the most cost effective 
programs for given number of jobs created. The approved and financed projects should be followed up and resources used should be checked by professional accountants holding project leaders responsible for their decisions. This is a normal practice in other transparent systems that have been able to root out corruption and create a society with decision makers and citizens assigned rights and obligations and also held responsible for their actions.

There should be official and centrally delegated guidelines for office hours and working time to promote discipline, high work moral, and respect for authority - elements of a normal, well functioning and effective work place and work conditions, which unfortunately entirely is missing in this part of the world. The system of multiple employments is a common practice where employees instead of working they use their time to commute between different work places to register and to cash in their monthly salaries. In a situation where most of the labor force is public employees, it is very harmful to misuse public scarce resources allocated to such single labor market employment program which takes up more than $60 \%$ of the public budget. Resources in addition to welfare enhancing programs should be used as incentives in best productive ways, and not as it is currently poorly for consumption purposes. There should be clear regulation and employment register to prevent abuse of the welfare system.

Accountability and transparency of the system are crucial to reform the labor market and to transfer it to a service provider organization. These are important tools to fight corruption and its negative effects on the work moral and discipline of the workforce. Skills, ability and efforts should be the key factors accounted for getting a job and the employees' promotion. Elements of corruption should be rooted out to save the new system under construction. Any postponement of efforts to eliminate corruption will be much costly in the future and it certainly endangers and undermines the entire political system. Destruction is always much faster and requires less efforts then construction. Efforts in any forms should be rewarded on a fair basis. A society run by inappropriate or illegal business and governance practices deter all sources of hope, jobs and making a living for citizens. In particular, it eliminates all efforts made to achieve the Kurds dreams. Thus, all efforts must be made to encourage the young generation to stay and to build up their society rather than becoming refugees and a burden to the industrialized countries.

It is still not late to reverse the direction of the emigration flow by facilitating employment of new high school and university graduates. The public resources should 
be used to create jobs and welfare not a base power for influential persons. The separation of public investment, working duties and personal business is necessary to be made. Many decision makers are sitting on too many chairs mixing work, business and personal relations in an obvious and biased way. Through various regulations and instructions they should be made understood on the short and long term negative effects of such misconduct and abuse of power.

\section{Summary}

This study is a descriptive analysis of the labor market conditions in Kurdistan in general. It explores a number of integrated factors that covariate and determine the level and patterns of the labor market outcomes in the region. These factors include: (i) mismatch of education and skills required on the job market, (ii) low quality and insufficient education to create new job opportunities, (iii) high wage rate resulting in low labor productivity and competitiveness in the region, (iv) non-optimal capital investment, high risk and unknown prospects for future development, (v) high profitability of import and distribution of commodities compared to local production, and finally (vi) absent of well-functioning labor market institutions, lack of statistics and active labor market policy measures to promote production and employment creation. In this study, first I describe each of the determinants of unemployment and establish their causal and directions of possible effects. In the second step, investigate the characteristics of the current labor market policy. Finally, after providing knowledge about the nature of (un)employment and current policy measures, a number policy measures are proposed to reduce the rate of unemployment or to reduce the negative effects of unemployment and to promote skills, capability and development potential. 


\section{References}

Adams R.H. and J. Page (2003), Poverty, inequality and growth in selected Middle East and North Africa countries, 1980-2000, World Development 31(12), 2027-2048.

Addison T. and A. Heshmati (2004), The new global determinants of FDI flows to developing countries: The impacts of ICT and democratization, Research in Banking and Finance 4, 151-186.

Amaral A. and P. Teixeira (2000), The rise and fall of the private sector in Portuguese higher education, Higher Education Policy 1383), 245-266.

Assaad R. and M. Arntz (2005), Constrained geographical mobility and gendered labor market outcomes under structural adjustment: Evidence from Egypt, World Development 33(3), 431-454.

Baslevent C. and Ö. Onaran (2004), The effect of export-oriented growth on female labor market outcomes in Turkey, World Development 32(8), 1375-1393.

Baumgartner H.J. and V. Steiner (2006), Does more generous student aid increase enrolment rates into higher education? Evaluating the German student aid reform of 2001, IZA Discussion Papers 2006:2034.

Belzil C. (2000), Job creation and job destruction, worker reallocation, and wages, Journal of Labor Economics 18(2), 183-203.

Bleiklie I. (2000), Policy regimes and policy change: comparing higher education reform policy in three European countries, Comparative Social Research 19, 101-138.

Branscomb L.M. and Y-H. Kim (1996), Eds. Korea at the turning point: Innovation-based strategies for development, Westport, Connecticut, London: Praeger.

Cardoso A.R. (2004), Jobs for young university graduates: Is it worth having a degree?, IZA Discussion Papers 2004:1311.

Cardoso A.R. and P. Ferreira (2002), The dynamics of job creation and destruction for university graduates: Why a rising unemployment rate can be misleading, IZA Discussion Papers 2002:623.

Catsro C.D.M. and D.C. Levy (2000), Myth, reality, and reform: Higher education policy in Latin America, Inter-American Development Bank, Washington, D.C. 
Cornwell C., K-H. Lee and D.B. Mustard (2006), The effects of state-sponsored merit scholarships on course selection and major choice in college, IZA Discussion Papers 2006:1953.

Dundar H. and D.R. Lewis (1999), Equity, quality and efficiency effects of reform in Turkish higher education, Higher Education Policy 12(4), 343-366.

Gungör N.D. and A. Tansel (2005), The determinants of return intentions of Turkish students and professionals residing abroad: An empirical investigation, IZA Discussion Papers 2005:1598.

Haouas I., M. Yagoubi and A. Heshmati (2003), Labour-use efficiency in the Tunisian's manufacturing industries: A flexible adjustment model, The Review of Middle East Economics and Finance 1(3), 195-214.

Heshmati A. (2003), Productivity growth, efficiency and outsourcing in manufacturing and services, Journal of Economic Surveys 17(1), 79-112.

Heshmati A. and I. Haouas (2004), The effects of union wage-settings on firms production factor decisions, Applied Economics Letters 11, 415-420.

Li H. (2003), Economic transition and returns to education in China, Economics of Education Review 22(3), 317-328.

Marope P.T.M. (1996), The impact of educational policy reforms on the distribution of educational outcomes in developing countries: The case of Botswana, International Journal of Educational Development 16(2), 157-171.

Masso J. and A. Heshmati (2004), Optimality and overuse of labour in Estonian manufacturing enterprises, Economics of Transition 12(4), 683-720.

Mehta S.R. (2000), Quality of education, productivity changes, and income distribution, Journal of Labor Economics 18(2), 252-281.

Miles R. (2002), Employment and Unemployment in Jordan: The Importance of the Gender System, World Development 30(3), 413-427.

Minami R., et al. (1995), Acquiring, adapting and developing technologies: Lessons from the Japanese experiences, London, UK: The Macmillan Press.

Mok K-H. (2005), Fostering entrepreneurship: changing role of government and higher education governance in Hong Kong, Research Policy 34(4), 537-554. 
Moock P.R., H.A. Patrinos and M. Venkataraman (2003), Education and earnings in a transition economy: The case of Vietnam, Economics of Education Review 22(5), 503-510.

Okimoto D. I. (1989), Between MITI and the market: Japanese industrial policy for high technology, Stanford, California: Stanford University Press.

Reiko Y. (2001), University reform in the post-massification era in Japan: Analysis of government education policy for the $21^{\text {st }}$ century, Higher Education Policy 14(4), 277-291.

Tasci H.M. and A. Tansel (2005), Unemployment and transition in the Turkish labor market: Evidence from individual level data, IZA Discussion Papers 2005:1663.

Taylor R.D. (2003), The Malaysia experience: The Multimedia Super Corridor, in: Jussawalla M. and R.D. Taylor, Eds. Information technology parks of the Asia Pacific: Lessons for the regional digital divide, M.E. Sharpe, Armonk, New York, pp 64-118.

Thomas H.G. (2001), Towards a new higher education law in Lithuania: Reflections on the process of policy formulation, Higher Education Policy 14(3), 213-223.

Tomusk V. (2001), Higher education reform in Estonia: A Legal perspective, Higher Education Policy 14(3), 201-212.

Walker I. and Y. Zhu (2005), The college wage premium, overeducation, and the expansion of higher education in the UK, IZA Discussion Papers 2005:1627.

Walters B., D. Hall, F. Nixon and P. Stubbs (1999), Institutional change in a transitional economy: The reform of economics higher education in Mongolia, International Journal of Educational Development 19(6), 423-439. 